J. Lake Sci. (湖泊科学), 2012, 24(2): 197-205

http: //www. jlakes.org. E-mail : jlakes@niglas.ac.cn

(C) 2012 by Journal of Lake Sciences

\title{
三峡水库香溪河流域梯级水库浮游植物群落结构特征"
}

申恒伦 ${ }^{1,2}$, 蔡庆华 ${ }^{1 * *}$, 郡美玲 ${ }^{1,3}$, 徐耀阳 ${ }^{1,3}$

(1: 中国科学院水生生物研究所淡水生态与生物技术国家重点实验室,武汉 430072)

(2: 中国科学院研究生院,北京 100049)

(3: 安徽师范大学生命科学学院, 芜湖 241000)

摘 要: 于 2005 年 10 月、2006 年 1、4、7 月对三峡水库香溪河流域 3 座水库 (古洞口一级水库、古洞口二级水库和香溪河 库湾) 组成的梯级水库的浮游植物种类组成、优势种、群落结构、密度和生物多样性指数进行了周年调查研究. 共鉴定出 浮游植物 7 门 58 属 121 种 (含变种), 以绿藻和硅藻种类最多, 绿藻有 26 属 49 种, 占 $40.50 \%$; 硅藻 14 属 41 种, 占 $33.88 \%$; 其次是甲藻, 3 属 11 种, 占 $9.09 \%$; 蓝藻 5 属 7 种, 占 $5.79 \%$; 隐藻 3 属 7 种, 占 $5.79 \%$; 其它藻类仅占 $4.96 \%$. 浮 游植物在古洞口一级水库共有 25 属 31 种, 古洞口二级水库 29 属 40 种, 香溪河库湾 46 属 81 种. 优势度分析显示: 古洞口 一级水库藻类优势类群为硅藻门、绿藻门, 古洞口二级水库为硅藻门、隐藻门和甲藻门, 香溪河库湾为绿藻门、硅藻门、甲 藻门和隐藻门. 3 座水库浮游植物年均密度分别为 $1.110 \times 10^{6} 、 4.837 \times 10^{5}$ 和 $1.734 \times 10^{6} \mathrm{cells} / \mathrm{L}$; 其中, 最高密度出现在 香溪河库湾 $\left(4.87 \times 10^{6} \mathrm{cells} / \mathrm{L}\right)$, 最低密度出现在古洞口二级水库 $\left(5.76 \times 10^{5} \mathrm{cells} / \mathrm{L}\right)$. 运用主成分分析对梯级水库进行 水质分析, 表明沿着水库的梯度水质逐渐恶化. Shannon-Wiener 多样性指数和 Pielou 均匀度指数在 3 座水库间无明显差 异, 而香溪河库湾 Margalef 丰富度指数显著大于古洞口一级、二级水库. 前两个指数与浮游植物优势种的评价结果显示, 香溪河流域梯级水库处于中污染状态.

关键词: 香溪河流域;梯级水库;浮游植物;优势类群;多样性评价; 群落结构;三峡水库

\section{Community structure characteristics of phytoplankton along a cascade of reservoirs in Xiangxi River Basin, Three Gorges Reservior}

\author{
SHEN Henglun ${ }^{1,2}$, CAI Qinghua ${ }^{1}$, SHAO Meiling ${ }^{1,3} \&$ XU Yaoyang ${ }^{1,3}$ \\ (1: State Key Laboratory of Freshwater Ecology and Biotechnology of China, Institute of Hydrobiology, Chinese Academy of \\ Sciences, Wuhan 430072, P. R. China) \\ (2: Graduate University of Chinese Academy of Sciences, Beijing 100049, P. R. China) \\ (3: College of Life Science, Anhui Normal University, Wuhu 241000, P. R. China)
}

\begin{abstract}
Xiangxi River originates from the Shennongjia Forest region and is the largest tributary in Hubei Province of Three Gorges Reservoir. Three reservoirs(Gudongkou Reservoir 1, Gudongkou Reservoir 2 and Xiangxi Bay of Three Gorges Reservoir) in Xiangxi River Basin were selected to investigate phytoplankton ecology in such a reservoir cascade system. In this study, phytoplankton composition, dominant species, community structure, abundance and biodiversity index were investigated and analyzed from October 2005 to July 2006. A total of 121 species, belonging to 58 genera in 7 phyla were identified, among which Chlorophyta (49 species of 26 genera) is the most important compontent, accounting for $40.50 \%$ of the total; followed by Bacillariophyta (41 species of 14 genera) for 33.88\%, and Pyrrophyta(11 species of 3 genera) for $9.09 \%$, Cyanophyta( 7 species of 5 genera) for $5.79 \%$, Cryptophyta( 7 species of 3 genera) for $5.79 \%$ and other species for $4.96 \%$. 31 species of 25 genera, 40 species of 29 genera and 81 species of 46 genera were found in Gudongkou Reservoir 1, 2, and Xiangxi Bay, respectively. The dominant species in Gudongkou Reservoir 1 belonged to Bacillariophyta, Chlorophyta, while Bacillariophyta, Cryptophyta and Pyrrophyta
\end{abstract}

* 国家自然科学基金项目 (40671197)、国家水体污染控制与治理科技重大专项项目 (2009ZX07528-003-04-01)、中国 科学院知识创新工程重要方向项目 (KZCX2-YW-427) 和国家重点实验室专项经费项目 (Y15B021F01) 联合资助. $2011-11$ - 01 收稿;2011-12-19 收修改稿. 申恒伦,男,1983 年生,博士研究生;E-mail: shenhenglun@ gmail. com.

** 通信作者;E-mail: qhcai@ ihb. ac. cn. 
dominated in Gudongkou Reservoir 2. Chlorophyta, Bacillariophyta, Pyrrophyta, Cryptophyta also played an important role in Xiangxi Bay. The annual abundance of phytoplankton community in the three reservoirs was $1.110 \times 10^{6}, 4.837 \times 10^{5}$ and $1.734 \times 10^{6}$ cells/L, respectively. It had highest density in Xiangxi Bay $\left(4.87 \times 10^{6}\right.$ cells/L) and lowest density in Gudongkou Reservoir $2\left(5.76 \times 10^{5}\right.$ cells/L). Principal Component Analysis was applied to analyze the water quality of the three reservoirs. The result implies that the water quality was degrading along the cascade of reservoirs. There were no significant differences in diversity index $(H)$ and evenness $(J)$ among the three reservoirs, while the Margalef index of Xiangxi Bay was significantly larger than that of Gudongkou Reservoir 1 and Gudongkou Reservoir 2. The valuation results by the first two indices and dominant phytoplankton species showed that the cascade reservoirs in Xiangxi River Basin were of intermediate pollution state.

Keywords : Xiangxi River Basin; cascade of reservoirs ; phytoplankton; dominant category ; diversity evaluation; community structure; Three Gorges Reservoir

河流筑坝滚动开发, 形成一系列梯级水库,这在很大程度上改变了流域原来的水文节律过程,如: 水库 的梯级开发打断了原来的“河流连续统” (River Continuum Concept, RCC $)^{[1]}$, 使河流连续性受到破坏, 形成 了“梯级水库连续统” (The Cascading Reservoir Continuum Concept, CRCC) ${ }^{[2]}$. 我国有着丰富的水能资源, 且 开发潜力巨大,在社会发展与国民经济建设中起着巨大的作用. 作为世界上水能资源最丰富的国家之一, 我 国水库的梯级开发已经非常普遍 ${ }^{[3]}$. 长江、黄河等河流的梯级水库以惊人速度增加, 部分河流缺乏有效管理 导致断流、水污染等事件的发生 ${ }^{[4]}$. 国内对梯级水库的研究起步较晚,早期多集中在联合优化调度、水文学 等方面 ${ }^{[5-7]}$. 近年来, 随着对梯级水库生态学研究的逐步深人, 梯级水库对生态系统与水环境的影响正逐步 引起国内学者的关注 ${ }^{[3,8-12]}$. 国际上对梯级水库的生态学研究相对较早, 如 Straskraba 对捷克伏尔塔瓦河 ( Vltava) 上的 6 座水库开展的水库湖沼学研究 ${ }^{[13]}$. 除了水文学方面 ${ }^{[14]}$, 捷克、巴西等国对梯级水库水生生物与 水环境方面的研究也较多. 如捷克学者研究了梯级与非梯级水库水力发电对鱼存量的影响 ${ }^{[15]}$; 俄罗斯学者 Karnaukhova 对 Angara 梯极水库的底部沉积的岩石地化循环差异进行研究 ${ }^{[16]}$; Hart 等对南非 Mgeni 河上的 梯级水库的浮游生物开展长期研究 ${ }^{[17-18]}$; 巴西学者对梯级水库生态学方面的研究较为细致全面, 涵盖了梯 级水库水体理化特征 ${ }^{[19]}$ 、浮游植物 ${ }^{[20-21]}$ 、浮游动物 ${ }^{[22-23]}$ 以及底栖动物群落 ${ }^{[24]}$.

位于香溪河中游的古夫河是香溪河三大支流之一, 流经兴山县新县城, 新县城上游和下游分别建有古 洞口一级水库和二级水库. 古洞口一级水利水电枢纽工程是以发电为主, 兼顾防洪、供水、灌溉、养殖等多种 效益的综合性水利工程, 水库正常蓄水高程 $325 \mathrm{~m}$, 最大坝高 $117.6 \mathrm{~m}$, 总库容 $1.476 \times 10^{8} \mathrm{~m}^{3}$,一级水库是兴 山县新县城工农业生产和居民生活的主要水源, 而二级水库恰好是兴山县新县城工农业生产和居民生活废 水的“收集器”.三峡水库 2003 年 6 月初期蓄水后,香溪河下游河段水位随之升高, 水流减缓, 水环境由典型 的河流水体转变为类似湖泊的缓流水体 (称为香溪河库湾) ${ }^{[25]}$. 香溪河库湾位于兴山县老县城 (高阳镇)下 游. 由于梯级水库是建在同一条河流上的连续水库,下一级水库承接了上一级水库排放的水, 因而存在着梯 度联系. 由此, 在香溪河流域内自上而下形成了独具生态格局的梯级水库 (库湾), 是水库梯级调度生态学效 应研究的理想平台. 流域水库梯级开发及其梯级调度, 在很大程度上改变了流域原来的水文、水质过程, 成 为水体富营养效应另一重要的叠加因素, 致使水体富营养化过程效应叠加进一步复杂化. 因此,有必要重点 研究流域水库梯级调度的生态学效应,为制定梯级水库水体富营养化的流域综合治理对策和水生生态系统 的健康状况、水环境评价以及水资源合理开发利用提供重要基础资料和理论依据. 香溪河流域梯级水库的 水生生物的研究仅有郡美玲等关于底栖动物的群落比较研究 ${ }^{[3]}$. 而浮游植物作为水体中主要的初级生产 者,在食物链中起着重要作用,同时也影响着湖泊的水质状况,其种类的组成和分布变化对环境的变化具有 指示作用 ${ }^{[26]}$. 为此, 本文将在分析 3 座水库浮游植物群落结构与多样性的基础上, 进行香溪河流域梯级水库 的比较生态学研究.

\section{1 材料和方法}

\section{1 采样时间和采样点设置}

采样时间为 2005 年 10 月、2006 年 1、4 和 7 月. 在古洞口一级水库设 4 个样点 (GD1-1 GD1-4), 古洞口 二级水库设 3 个样点 $(\mathrm{GD} 2-1 \sim \mathrm{GD} 2-3)$, 香溪河库湾设 8 个样点 $(\mathrm{XX} 01 \sim \mathrm{XX} 08$, 由于 XX08 是水库上游接近 
河流态的样点, 位置随水位的波动而发生改变, 故位置不固定, 因此未在样点图中标出) (图 1) ${ }^{[3]}$ 进行样品 采集.

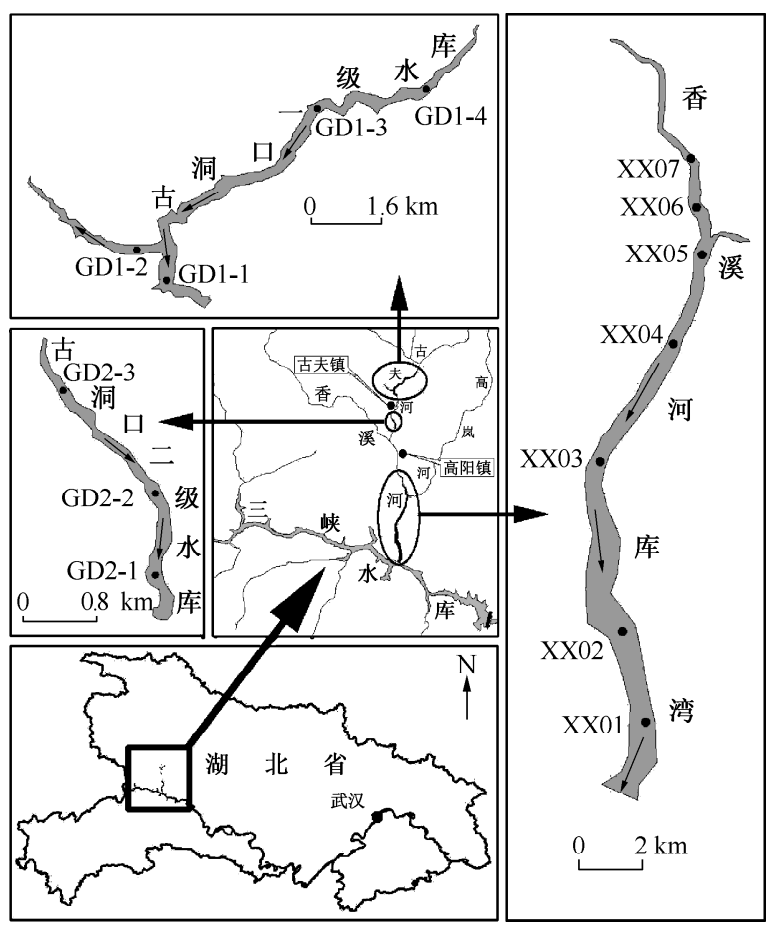

图 1 香溪河流域梯级水库采样点分布

Fig. 1 Distribution of sampling sites in the three reservoirs in Xiangxi River Basin

\section{2 样品采集与处理}

用柱状采水器采集 $5 \mathrm{~L}$ 表层混和水样, 取 $300 \mathrm{ml}$ 水样用浓硫酸酸化至 $\mathrm{pH}$ 值略小于 2 , 带回室内测定其 营养盐浓度; 取 $1220 \mathrm{ml}$ 水样现场用鲁哥氏液固定, 静置沉淀 $48 \mathrm{~h}$, 采用虹吸法浓缩到 $30 \mathrm{ml}$ 左右后添加适量 甲醛保存, 用于后续浮游植物的鉴定及定量分析 ${ }^{[27]}$.

水体透明度 (SD) 用萨氏圆盘 (Secchi disc) 现场测定; 采用 YSI 多参数水质测量仪 (YSI 6600 EDS) 现场 测量水温 (WT)、浊度 ( Turb)、溶解氧 $(\mathrm{DO}) 、 \mathrm{pH}$ 值等指标; 总氮 $(\mathrm{TN})$ 、硝态氮 $\left(\mathrm{NO}_{3}^{-}-\mathrm{N}\right)$ 、铵态氮 $\left(\mathrm{NH}_{4}^{+}-\mathrm{N}\right)$ 、 总磷 $(\mathrm{TP})$ 、正磷酸盐 $\left(\mathrm{PO}_{4}^{3-}-\mathrm{P}\right)$ 等水化学指标用流动分析仪 $(\mathrm{SAN}++, \mathrm{Skalar})$ 测定; 取 $0.1 \mathrm{ml}$ 的均匀亚样品 于浮游植物计数框中, 在日本 Olympus CX21 光学显微镜 $(10 \times 40)$ 下进行种类鉴定和计数 ${ }^{[28-29]}$.

\section{3 数据处理}

应用 SPSS 13.0 统计软件包进行方差和相关分析. Statistics 6.0 来进行主成分分析 (PCA).

优势种根据浮游植物物种的出现频率和相对数量来确定, 以优势度 $(y)$ 来表示, 当 $y>0.02$ 时, 定为优 势种. 计算公式为: $y=f_{i} \times P_{i}$, 其中 $f_{i}$ 为第 $i$ 种出现的频率, $P_{i}$ 为第 $i$ 种个体数量占总个体数量的比例 ${ }^{[30]}$.

为避免使用单一多样性指数造成的多样性评价分析偏差, 同时运用 Shannon-Wiener 多样性指数 $(H)$ 、 Margalef 丰富度指数 $(D)$ 、Pielou 均匀度指数 $(J)$ 对浮游植物群落特征进行分析. 计算公式分别为 ${ }^{[31-33]}: H=$ $-\sum P_{i} \log _{2} P_{i} ; D=(S-1) / \ln N ; J=H / \log _{2} S$; 式中, $P_{i}=N_{i} / N, S$ 为群落中的种类数, $P_{i}$ 为第 $i$ 种个体数量占总 个体数量中比例, $N$ 为所有种个体总数, $N_{i}$ 为第 $i$ 种个体数量.

\section{2 结果与分析}

\section{1 环境基本特征}

3 座水库 (库湾) 的理化因子的统计结果表明,沿着水库梯度水体的理化环境发生了改变,水体中叶绿 
素 $\mathrm{a} 、$ 氮、磷、硅等营养盐浓度逐渐增加, 碱度 (Alk) 逐渐减低; 位于河流中游的古洞口二级水库的水温、透明 度最低, 而电导率 (Cond)、化学需氧量 (COD)、 $\mathrm{pH}$ 等指标却高于古洞口一级水库和香溪河库湾 (表 1).

表 1 香溪河流域三座梯级水库的理化因子

Tab. 1 Physical and chemical factors of the three reservoirs in Xiangxi River Basin

\begin{tabular}{|c|c|c|c|c|c|c|c|c|c|}
\hline \multirow{2}{*}{ 理化因子 } & \multicolumn{3}{|c|}{ 古洞口一级水库 } & \multicolumn{3}{|c|}{ 古洞口二级水库 } & \multicolumn{3}{|c|}{ 香溪河库湾 } \\
\hline & 均值 & 标准差 & 变异系数 & 均值 & 标准差 & 变异系数 & 均值 & 标准差 & 变异系数 \\
\hline $\mathrm{WT} /{ }^{\circ} \mathrm{C}$ & 19.64 & 6.62 & 0.34 & 18.70 & 5.69 & 0.30 & 21.93 & 8.84 & 0.40 \\
\hline Cond $/(\mu \mathrm{S} / \mathrm{cm})$ & 269.25 & 131.16 & 0.49 & 314.89 & 72.92 & 0.23 & 207.67 & 148.64 & 0.72 \\
\hline $\mathrm{COD} /(\mathrm{mg} / \mathrm{L})$ & 2.15 & 0.61 & 0.28 & 2.63 & 0.62 & 0.24 & 2.57 & 0.42 & 0.16 \\
\hline Chl. a/ $(\mu \mathrm{g} / \mathrm{L})$ & 5.69 & 2.95 & 0.52 & 12.41 & 13.01 & 1.05 & 13.18 & 18.21 & 1.38 \\
\hline Turb/NUT & 14.09 & 22.24 & 1.58 & 37.03 & 25.45 & 0.69 & 26.46 & 24.69 & 0.93 \\
\hline $\mathrm{Alk} /(\mathrm{mg} / \mathrm{L})$ & 156.41 & 9.55 & 0.06 & 151.82 & 16.04 & 0.11 & 133.76 & 19.05 & 0.14 \\
\hline $\mathrm{SD} / \mathrm{cm}$ & 319.31 & 53.30 & 0.17 & 107.75 & 47.03 & 0.44 & 155.79 & 99.80 & 0.64 \\
\hline $\mathrm{pH}$ & 7.45 & 1.74 & 0.23 & 8.33 & 0.37 & 0.04 & 7.41 & 2.80 & 0.38 \\
\hline $\mathrm{TN} /(\mathrm{mg} / \mathrm{L})$ & 0.94 & 0.32 & 0.34 & 1.30 & 0.55 & 0.42 & 1.46 & 0.43 & 0.30 \\
\hline $\mathrm{NO}_{3}^{-}-\mathrm{N} /(\mathrm{mg} / \mathrm{L})$ & 0.56 & 0.12 & 0.21 & 0.80 & 0.27 & 0.34 & 0.98 & 0.32 & 0.32 \\
\hline $\mathrm{NH}_{4}^{+}-\mathrm{N} /(\mathrm{mg} / \mathrm{L})$ & 0.06 & 0.06 & 0.99 & 0.14 & 0.17 & 1.26 & 0.07 & 0.06 & 0.87 \\
\hline $\mathrm{TP} /(\mathrm{mg} / \mathrm{L})$ & 0.02 & 0.01 & 0.34 & 0.05 & 0.02 & 0.47 & 0.15 & 0.09 & 0.59 \\
\hline $\mathrm{PO}_{4}^{3-}-\mathrm{P} /(\mathrm{mg} / \mathrm{L})$ & 0.02 & 0.01 & 0.50 & 0.04 & 0.01 & 0.37 & 0.10 & 0.09 & 0.82 \\
\hline $\mathrm{SiO}_{2}-\mathrm{Si} /(\mathrm{mg} / \mathrm{L})$ & 3.15 & 0.85 & 0.27 & 4.61 & 0.97 & 0.21 & 5.67 & 0.95 & 0.17 \\
\hline
\end{tabular}

拦河筑坝和水利调度,不仅改变了水体的水动力学条件,而且对上游河段物质的拦截和下游河流物质输 送造成了不同程度的影响. 有研究表明, 筑坝对水体中营养物质具有拦截效应 ${ }^{[34]}$. 但是, 香溪河流域的 3 个水库 (库湾) 的营养盐浓度呈现逐级增加的趋势, 水体营养状态已由上游的中营养向香溪河的富营养化转变. 这可能与 古洞口二级水库与香溪河库湾周边城镇居民的生活污染以及农业污染有关,应当引起相关部门的重视.

由于 $\mathrm{TN}$ 与 $\mathrm{NO}_{3}^{-}-\mathrm{N} 、 \mathrm{SiO}_{2}-\mathrm{Si}$ 显著相关 $(r=0.964,0.821, P<0.01)$, $\mathrm{TP}$ 与 $\mathrm{PO}_{4}^{3-}-\mathrm{P}$ 显著相关 $(r=0.996$, $P<0.01), \mathrm{SD}$ 与 $\mathrm{SiO}_{2}-\mathrm{Si}$ 显著相关 $(r=-0.742, P=0.02), \mathrm{COD}$ 与 $\mathrm{TN} 、 \mathrm{NO}_{3}^{-}-\mathrm{N}$ 显著相关 $(r=0.750,0.713$, $P<0.05$ ), 因而在进行主成分分析时剔除 $\mathrm{NO}_{3}^{-}-\mathrm{N} 、 \mathrm{SiO}_{2}-\mathrm{Si}_{、} \mathrm{PO}_{4}^{3-}-\mathrm{P} 、 \mathrm{COD}$, 得到环境因子与样点的得分图 (图 2).
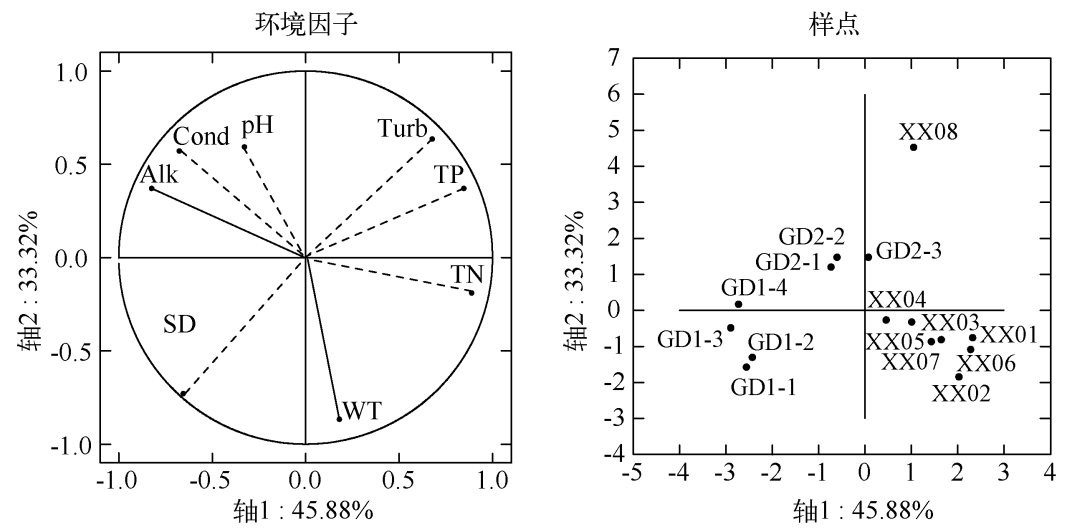

图 2 环境指标主成分分析

Fig. 2 Principle Component Analysis comparing the water quality of the three reservoirs

3 座水库 (库湾) 的环境差异非常明显, 在 PCA 图上占据了不同的区域. 在前两轴上就得到了很好的分 化, 解释率达 $79.2 \%$. 在解释率最高的第一轴上, 3 座水库发生明显的分化, 古洞口二级水库的水质介于古 洞口一级水库与香溪河库湾之间. 古洞口一级水库 $\mathrm{TN} 、 \mathrm{TP}$ 都较低且碱度和透明度较大, 香溪河库湾 $\mathrm{TP} 、 \mathrm{TN}$ 
都较高, 碱度、透明度较低. 水体中氮、磷营养盐浓度自上游到下游水库逐渐升高, 说明沿着水库梯度, 水质 逐渐恶化. 古洞口二级水库在反映 $\mathrm{pH}$ 和 Turb 信息的第二轴上与其他两个水库发生明显分化, 表明古洞口 二级水库这两个参数值较高. 除了 Turb、WT、Cond、COD 以及 $\mathrm{NH}_{4}^{+}-\mathrm{N}$ 含量外, 3 座水库在其他参数方面大体 呈现随水库梯度逐渐增加或减少的趋势. 由于受到浊度、TP、碱度以及电导率的影响, 位于水库最上游的接 近河流态的样点偏离了各自水库的样点群. 每个水库除去上游的样点外, 水库内样点间的水质差异不显著. 古洞口二级水库的分化可能与其运行方式与上游古洞口一级水库下泄水的影响有关. 因为古洞口二级水库 属于日调节型水库, 其回水长度较短、流速较快、水体滞留时间较短, 而且受到上游水库低温下泄水的影响, 所以古洞口二级水库的水温和水体透明度较低.

\section{2 浮游植物组成}

调查期间共采集到浮游植物 7 门 58 属 121 种 (含变种), 以绿藻门和硅藻门种类最多, 其中绿藻门有 49 种 (占 $40.50 \%$ )、硅藻门 41 种 (占 $33.88 \%$ )、甲藻门 11 种 (占 $9.09 \%$ )、蓝藻门和隐藻门各 7 种 (各占 $5.79 \%$ )、金藻门 4 种 (占 $3.31 \%$ )、裸藻门 2 种 (占 $1.65 \%$ ).

古洞口一级水库共鉴定 7 门 25 属 31 种, 主要有硅藻门(12 种) 和绿藻门(8 种); 古洞口二级水库鉴定 6 门 29 属 40 种, 其中硅藻门 19 种、绿藻门 14 种; 香溪河库湾共鉴定浮游植物 7 门 46 属 81 种, 硅藻门 20 种、 绿藻门 36 种. 3 座水库都以硅藻门、绿藻门种类占优势, 且沿水库梯度浮游植物种类逐渐增加, 绿藻门最终 超过硅藻门成为香溪河库湾的主要种类 (表 2). 其中湖生红胞藻 (Rhodomonas lacustris)、塔胞藻 (Pyramimonas sp. )、鱼鳞藻 (Mallomonas sp.) 、具尾蓝隐藻 (Chroomonas caudate) 只在香溪河库湾出现.

采样期间在 3 座水库 (库湾) 采集到的浮游植物总物种数随着水库梯度逐渐增加, 尤其是香溪河库湾 (81 个物种), 其物种数比前 2 个水库 (分别为 31 和 40 个物种) 增加明显. 这与底栖动物的研究结果一 致 ${ }^{[3]}$. 邵美玲等从河流连续统概念对底栖动物的结果进行了解释, 认为 “中级别河流其生物多样性比上游河 流会有所增加” ${ }^{[1]}$, 因此如果从河流级别来考虑, 可能更容易理解. 古洞口一级水库和古洞口二级水库都位 于古夫河上, 为同一级别的水库, 古夫河与湘坪河汇合后成为香溪河, 因此香溪河库湾的级别则高一级, 所 以古夫河上的 2 座水库总物种数相差不大.

表 23 座梯级水库浮游植物种类组成

Tab. 2 Species composition of phytoplankton in each reservoir in Xiangxi River Basin

\begin{tabular}{lcccccccc}
\hline 水库 & 硅藻门 & 绿藻门 & 甲藻门 & 蓝藻门 & 隐藻门 & 金藻门 & 裸藻门 & 总计 \\
\hline 古洞口一级水库 & 12 & 8 & 4 & 2 & 3 & 1 & 1 & 31 \\
古洞口二级水库 & 19 & 14 & 2 & 1 & 3 & 0 & 1 & 40 \\
香溪河库湾 & 20 & 36 & 8 & 5 & 7 & 3 & 2 & 81 \\
\hline
\end{tabular}

根据优势度分析, 香溪河流域三座梯级水库的浮游植物优势种可看出, 古洞口一级水库优势类群是绿 藻和硅藻, 分别为粗壮细鞘丝藻 (Leptolyngbya valderiana) 、单生卵囊藻 (Oocystis solitaria) 、空星藻 (Coelastrum sphaericum)、美丽星杆藻 (Asterionella formosa) 、小环藻 (Cyclotella sp. ) ; 古洞口二级水库优势种为美丽星杆 藻、小环藻、倪氏拟多甲藻 (Peridiniopsis niei) 和卵形隐藻 (Cryptomonas ovata) ; 香溪河库湾主要优势类群是隐 藻和硅藻, 分别为倪氏拟多甲藻、卵形隐藻、花环小环藻 (Cyclotella operculata) 、尖尾蓝隐藻 (Chroomonas acuta) 、实球藻 (Pandorina morum)、席藻 (Phormidium sp.) ; 小环藻和美丽星杆藻为古洞口一 级、二级水库的共有优势种; 倪氏拟多甲藻和卵形隐藻为古洞口二级水库与香溪河库湾的共有优势种.

基于水库基本类型综合分级方法,虽然都属于具有河流和湖泊特征的混合一分层过渡型水库,但在流域 面积、回水长度等方面的差异使得 3 个水库 (库湾) 存在明显差异. 流速较大、水体滞留时间较短的古洞口一 级与二级水库更接近河流态水体, 浮游植物群落中硅藻种类数最多, 而流速较小、水体滞留时间较长的香溪 河库湾则更接近湖泊态水体, 库湾的绿藻种类数 (36 种) 超过硅藻种类数 (20 种) 而占据主要地位.

\section{3 浮游植物密度}

各水体虽然都属于香溪河流域, 但浮游植物密度有明显差别. 香溪河库湾浮游植物年均密度最高, 达 $1.734 \times 10^{6} \mathrm{cells} / \mathrm{L}$, 其次为古洞口一级水库为 $1.110 \times 10^{6}$; 古洞口二级水库的年均浮游植物密度仅为 
$4.837 \times 10^{5}$ cells $/ \mathrm{L}$, 明显低于古洞口一级水库和香溪河库湾. 虽然古洞口二级水库形成时间最晚, 而且回水 长度在 3 个水库 (库湾) 中最短 (表 3 ), 但是作为一座日调节型水库, 其较短的水体滞留时间, 加之流速与年 均流量增大, 水体浊度增加, 透明度降低, 这在一定程度上影响了浮游植物对光的吸收利用, 加之水动力学 方面的改变, 从而改变了筑坝前河流态水体中浮游植物的群落结构, 使得古洞口二级水库的浮游植物种类 数较上游的古洞口一级水库有所增加, 但在年均密度上显著低于上游水库.

表 3 三个水库 (库湾) 的基本情况 ${ }^{[36]}$

Tab. 3 Basic habitat characteristics of the three reservoirs

\begin{tabular}{lcccc}
\hline 水库 & 流域面积 $/ \mathrm{km}^{2}$ & 回水长度 $/ \mathrm{km}$ & 年平均流量 $/\left(\mathrm{m}^{3} / \mathrm{s}\right)$ & 平均水体滞留时间 $/ \mathrm{d}$ \\
\hline 古洞口一级水库 & 965 & 14.00 & 19.9 & 67 \\
古洞口二级水库 & 1155 & 3.37 & 23.8 & 49 \\
香溪河库湾 & 3099 & 25.90 & 47.4 & 127 \\
\hline
\end{tabular}

古洞口一级水库的硅藻门密度最大, 为 $6.779 \times 10^{5} \mathrm{cells} / \mathrm{L}$, 其次是绿藻门, 年均密度为 $3.009 \times$ $10^{5} \mathrm{cells} / \mathrm{L}$; 硅藻门和绿藻门占据了浮游植物总数的 $88.09 \%$; 古洞口二级水库以硅藻门和甲藻门占优势, 年 均密度分别为 $2.090 \times 10^{5} 、 1.617 \times 10^{5} \mathrm{cells} / \mathrm{L}$; 在香溪河库湾, 绿藻门密度占优势 (占 $40.96 \%$ ), 达到 $7.114 \times$ $10^{5} \mathrm{cells} / \mathrm{L}$, 其次是隐藻门和硅藻门, 3 者共占浮游植物总密度的 $87.11 \%$ 以上. 古洞口二级水库的硅藻门和 隐藻门的密度处于其它两个水库之间, 除甲藻门密度高于古洞口一级水库与香溪河库湾外, 其余种类均显 著低于另外 2 个水库 $(P<0.05)$ (图 3 ). 沿着水库的梯度, 硅藻门细胞密度逐渐降低, 隐藻门细胞密度逐渐 升高, 这可能与水体的水动力条件和营养盐变化有较大关系, 滞留时间延长和营养盐增加, 使得隐藻门得以 在竞争中占优势.

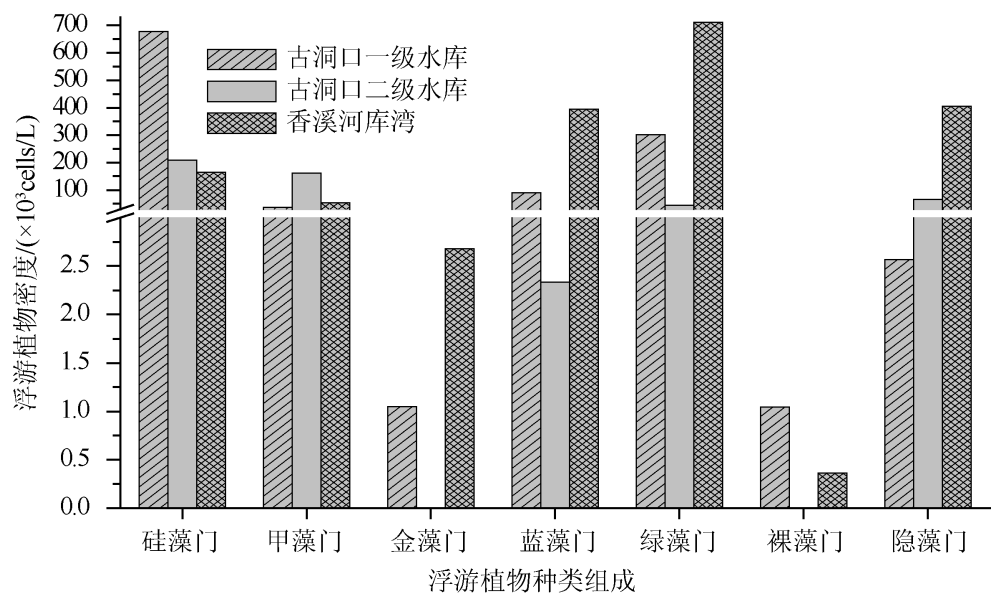

图 3 香溪河流域梯级水库浮游植物密度分布

Fig. 3 Distribution of phytoplankton density in the cascade reservoirs in Xiangxi River Basin

\section{4 浮游植物多样性}

3 座梯级水库的的多样性指数表明, Shannon-Wiener 多样性指数大小顺序为: 香溪河库湾 (1.09)>古洞 口一级水库 $(1.06)>$ 古洞口二级水库 $(0.89)$. Margalef 丰富度指数顺序为: 香溪河库湾 $(0.92)>$ 古洞口二 级水库 $(0.38)>$ 古洞口一级水库 $(0.34)$. Pielou 均匀度指数为: 古洞口一级水库 $(0.52)>$ 古洞口二级水库 $(0.43)>$ 香溪河库湾 $(0.38)$. Shannon-Wiener 多样性指数和 Pielou 均匀度指数在 3 座水库间无显著差异 $(P>0.05)$, 而香溪河库湾 Margalef 丰富度指数显著大于古洞口一级、二级水库 $(P<0.05)$. 虽然水库的总 物种数沿着水库梯度逐渐上升, 但是 Shannon-Wiener 多样性指数和 Pielou 均匀度指数并没有呈现类似的规 律, 用 Shannon-Wiener 多样性指数作为群落多样性的度量, 则生物多样性的最小值出现在古洞口二级水库, 
这显然与中度干扰假说不一致. 因为古洞口二级水库是日调节型水库, 水体滞留时间最短, 环境相对不稳 定, 按照中度干扰假说应该支持高的生物多样性 ${ }^{[37]}$. 从这个角度来看, 河流连续统在一定程度上被梯级水库 打断.

一般来说, 浮游植物的 $H$ 值越高, 其群落结构越复杂, 稳定性越大, 水质越好. 而当水体受到污染时, 敏 感型种类消失, $H$ 值减小, 群落结构趋于简单, 稳定性变差, 水质下降. 黄祥飞在利用多样性指数评价水体营 养状态时指出: 若 $H>3$, 轻或无污染; $1 \sim 3$, 中污染; $0 \sim 1$, 重污染; $D>3$, 轻或无污染; $1 \sim 3$, 中污染; $0 \sim 1$, 重 污染; $J$ 为 $0 \sim 0.3$, 重污染; $0.3 \sim 0.5$, 中污染; $0.5 \sim 0.8$, 轻或无污染 ${ }^{[35]}$. 基于 $H$ 值, 香溪河库湾和古洞口一 级水库群落结构较为复杂, 稳定性好, 水质较好, 古洞口二级水库群落结构较为简单, 稳定性差, 这可能与水 库的库龄和运行方式有着密切的关系. 古洞口一级水库形成时间最久, 库龄最长, 其水体极为清澈, 而古洞 口二级水库形成于 2004 年 4 月,香溪河库湾形成于三峡首次蓄水后. 因为库龄最小的古洞口二级水库环境 相对不稳定, 而且其水生态系统正处于由河流型向湖泊型转变的阶段, 因此浮游植物的 $H$ 值最低. 而基于 $D$ 值, 3 座水库均处于重污染状态 $(D<1)$; 均匀度指数 $J$ 的评价结果显示, 古洞口一级水库处于轻污染状态, 古洞口二级水库与香溪河库湾处于中污染状态. 基于 $T S I_{\mathrm{S}}$ 的水体营养状态评价显示 (未发表资料), 古洞口 一级水库处于中营养水平, 古洞口二级水库与香溪河库湾处于富营养水平. 这与 Shannon-Wiener 多样性指 数和 Pielou 均匀度指数的评价结果基本一致, 而 Margalef 丰富度指数则不适用于香溪河流域梯级水库的水 质评价.

多样性指数是反映均匀度和丰富度的综合指标 ${ }^{[37]}$. 本研究还显示, 梯级水库浮游植物的 $H$ 值与 $J$ 值、 $D$ 值都呈显著正相关, 相关系数分别为 $0.630(P=0.015)$ 和 $0.551(P=0.041)$. 由此可见, 在香溪河梯级水库 中浮游植物 Shannon-Wiener 多样性指数 $H$ 对 Margalef 丰富度 $D$ 敏感程度不大, 其浮游植物群落多样性提高 主要是由物种均匀度增加所致,故 Pielou 均匀度指数 $J$ 对多样性 $H$ 贡献较大.

\section{3 结论}

2005 年 10 月至 2006 年 7 月, 共鉴定浮游植物 7 门 58 属 121 种 (含变种), 以绿藻门和硅藻门种类最 多, 占总数的 $74.38 \% .3$ 座水库虽都以硅藻门、绿藻门种类居多, 但在浮游植物优势种、特有种和年均密度 之间存在差异. 古洞口一级与二级水库的物种组成差异不明显, 但 2 个水库与香溪河库湾的物种组成差异 较大. 例如湖生红胞藻、塔胞藻、鱼鳞藻和具尾蓝隐藻只在香溪河库湾中出现.

古洞口一级水库优势类群是绿藻和硅藻, 古洞口二级水库主要优势类群是硅藻, 香溪河库湾优势类群 是隐藻和硅藻. 其中小环藻和美丽星杆藻为古洞口一级 二级水库的共有优势种; 倪氏拟多甲藻和卵形隐藻 为古洞口二级水库与香溪河库湾的共有优势种.

在浮游植物密度方面, 水库年龄最短的古洞口二级水库的年均浮游植物密度低于古洞口一级水库与香 溪河库湾. 水库的浮游植物群落结构特征表明: 古洞口一级水库、古洞口二级水库仍属于河流型向湖泊型过 渡初期的水库, 而香溪河库湾的湖泊化程度相对较高. 中营养型湖泊中常以甲藻、隐藻、硅藻类占优势, 富营 养型湖泊则常以绿藻、蓝藻类占优势 ${ }^{[26]}$, 因此香溪河流域梯级水库处于中营养状态.

物种多样性是群落组织独特的生态学特征, 它反映了群落特有的物种组成和个体密度特征 ${ }^{[26]}$. 多样性 指数显示, 香溪河库湾和古洞口一级水库浮游植物群落结构较为稳定, 古洞口二级水库群落结构稳定性差. 利用 Shannon-Wiener 多样性指数 $H$ 和 Pielou 均匀度指数 $J$ 的评价结果与 $T S I_{\mathrm{S}}$ 和群落结构的评价结果基本一 致, 香溪河梯级水库间的水质营养状况基本相当, 为中营养类型. 香溪河流域梯级水库 $H$ 值与 $J$ 值、 $D$ 值都 呈显著正相关,但 $H$ 对 $D$ 敏感程度不大,而 $J$ 对 $H$ 贡献较大.

致谢: 野外采样及室内样品分析得到叶麟、李凤清、刘瑞秋等大力协助, 在此一并感谢.

\section{4 参考文献}

[1] 唐 涛, 黎道丰, 潘文斌等. 香溪河河流连续统特征研究. 应用生态学报, 2004, 15(1):141-144.

[ 2 ] Barbosa FAR, Padisak J, Espindola ELG. The cascading reservoir continuum concept(CRCC) and its application to the river tiete-basin, Sao paulostate, Brazil. In: Tundisi JG, Straskraba M eds. Theoretial reservoir ecology and its applica- 
tion. Leiden: Backhuys Publishers, 1999.

[3] 邵美玲, 韩新芹, 谢志才等. 香溪河流域梯级水库底栖动物群落的比较研究. 生态学报, 2007, 27 (12): 4963-4971.

[4] 国家环境保护局自然保护司. 黄河断流与流域可持续发展. 北京: 中国环境科学出版社, 1997.

[ 5] 韩 霜, 董正举, 王 欢等. 梯级水电站开发对香溪河悬浮颗粒物粒径及浓度的影响. 生态学报, 2008, 28(8): 3991-3997.

[6] 周玉琴. 三峡梯级与清江梯级联合调度研究 [学位论文]. 武汉: 武汉大学, 2005.

[7] 陈 进, 黄 薇. 梯级水库对长江水沙过程影响初探. 长江流域资源与环境, 2005, 14(6): 786-791.

[8] 简 东, 黄道明, 常秀岭等. 运红水河干流梯级运行后底栖动物的演替. 水生态学杂志, 2010, 3(6): 12-18.

[9] 杨 昆, 邓 熙, 李学灵等. 梯级开发对河流生态系统和景观影响研究进展. 应用生态学报, 2011, 22(5): 13591367.

[10] 陈 浒, 李厚琼, 吴 迪等. 乌江梯级电站开发对大型底栖无脊椎动物群落结构和多样性的影响. 长江流域资源 与环境, $2010,19(12): 1462-1470$.

[11] 徐建新, 丁占稳, 温随群等. 黄河干流梯级水库对河流生态系统的影响. 人民黄河, 2007, 29(10): 7-11.

[12] 黄报远, 李秋华, 陈桐生. 广东连江梯级电站开发后春季河流浮游生物群落结构特征. 安徽农业科学, 2009,37 ( 7 ) : 3137-3140.

[13] Straskraba M. Vltava cascade as teaching groups for reservoir limnology. Water Science and Technology, 1994, 30(10): 289-297.

[14] Matsuno Y, Tasumi M, Hoek W et al. Analysis of return flows in a tank cascade system in Sri Lanka. Paddy and Water Environment, 2003, 1(4): 173-181.

[15] Drastik V, Kubecka J, Tuser M et al. The effect of hydropower on fish stocks: Comparison between cascade and non-cascade reservoirs. Hydrobiologia, 2008, 609: 25-36.

[16] Karnaukhova GA. Lithological-geochemical differentiation of bottom deposits in the Angara cascade reservoirs. Geochemistry International, 2007,45 (4) : 390-398.

[17] Hart RC. Two calanoids, two lakes, and a decade or two. An updated record and evaluation of occurrence and periodicity of Tropodiaptomus spectabilis and Metadiaptomus meridianus (Copepoda: Calanoida), and alternative stable states in two cascading impoundments. Hydrobiologia, 2001, 453/454 (1) : 269-283.

[18 ] Hart RC. Cladoceran periodicity patterns in relation to selected environmental factors in two cascading warm-water reservoirs over a decade. Hydrobiologia, 2004, 526 (1) : 99-117.

[19] Adriana J, Marcos G. Temporal and spatial patterns based on sediment and sediment-water interface characteristics along a cascade of reservoirs(Paranapanema River, south-east Brazil). Lakes and Reservoirs: Research and Management, 2005, $10: 1-12$.

[20] Padisak J, Barbosa FAR, Borbely G et al. Phytoplankton composition, biodiversity and a pilot survey of toxic cyanoprokaryotes in a large cascading reservoir system( Tiete basin, Brazil). Verh Internat Verein Limnol, 2000, 27 : $2734-2742$.

[21] da Silva CA, Train S, Rodrigues LC. Phytoplankton assemblages in a Brazilian subtropical cascading reservoir system. Hydrobiologia, 2005, 537 (123) : 99-109.

[22] Gilmar PN, Marcos GN. Multi-dimensional effects on Cladoceran (Crustacea, Anomopoda) assemblages in two cascade reservoirs in Southeast Brazil. Lakes and Reservoirs: Research and Management, 2010, 15: 139-152.

[23] Marcos GN, Paula CRO, Yvana TDB. Zooplankton assemblages (Copepoda and Cladocera) in a cascade of reservoirs of a large tropical river(SE Brazil). Limnetica, 2008, 27(1): 151-170.

[24] Callisto M, Goulart M, Barbosa FAR et al. Biodiversity assessment of benthic macroinvertebrates along a reservoir cascade in the lower São Francisco River(northeastern Brazil). Brazilian Journal of Biology, 2005, 65 (2) : 229-240.

[25] 徐耀阳, 叶 麟, 韩新芹等. 香溪河库湾春季水华期间水体光学特征及相关分析. 水生生物学报, 2006, 30 (1): 84-88.

[26] 沈会涛, 刘存歧. 白洋淀浮游植物群落及其与环境因子的典范对应分析. 湖泊科学, 2008, 20(1): 773-779.

[27] 蔡庆华. 水域生态系统观测规范——中国生态系统研究网络 (CERN) 长期观测规范丛书. 北京: 中国环境科学出 版社, 2007.

[28] 胡鸿钧, 魏印心. 中国淡水藻类——系统、分类及生态. 北京: 科学出版社, 2006. 
[29] 章宗涉, 黄祥飞. 淡水浮游生物研究方法. 北京: 科学出版社, 1991.

[30 ] Lampitt RS, Wishner KF, Turley CM et al. Marine snow studies in the Northeast Atlantic Ocean: Distribution, composition and roles as a food source for migrating plankton. Marine Biology, 1993, 116(4) : 680-702.

[31] Shannon CE. A mathematical theory of communication. Bell System Technical Journal, 1948, 27: 379-423, 623-656.

[32] Margalef DR. Information theory in ecology. General Systems, 1958, 3: 36-71.

[33] Pielou EC. An introduction to mathematical ecology. New York: Wiley-Interscience, 1969.

[34] 黎慧卉, 刘丛强, 汪福顺等. 猫跳河流域梯级水库磷的夏季变化特征. 长江流域资源与环境, 2009, 18 (4): $368-372$.

[35] 黄祥飞, 陈伟民, 蔡启铭. 湖泊生态调查观测与分析. 北京: 中国标准出版社, 1999: 27-105.

[36] 邵美玲. 水库群底栖动物生态学研究一一三峡水库湖北段和香溪河流域为例 [学位论文]. 武汉: 中国科学院 水生生物研究所, 2008 .

[37] 李 博, 孙儒泳. 普通生态学. 北京: 高等教育出版社, 1993: 135-138. 